\title{
Otel İşletmelerinde Öğrenilmiş Çaresizlik ve Kariyer Planlaması Arasındaki İlişkinin Analizi
}

\author{
Bülent Kurtuluş GÖNÜL ${ }^{1}$ ve Mahmut DEMIR ${ }^{2}$
}

$\ddot{O} z$

Bu çalışmanın amacı, Ankara'daki otel işletmelerinde öğrenilmiş çaresizlik ve kariyer planlaması arasındaki ilişkiyi analiz etmektir. Özel işletme belgeli oteller ile 3 yldızlı otellerden 5 yldızlı otellere kadar toplam 84 otelden 405 kişiye uygulanan ankette 21 öğrenilmiş çaresizlik ve 10 kariyer planlaması ile ilgili değişkenler yer almaktadır. Araştırmacılar tarafından yüz yüze görüşme yapılarak elde edilen veriler SPSS (Statistical Package for the Social Sciences) istatistik programı ile analiz edilmiştir. Öncelikle verilerin yapısal ve yakınsak geçerliliği faktör analizi ile ortaya konulmuştur. Öğrenilmiş çaresizlik ve kariyer planlaması değişkenlerinin boyutlarını belirlemek için faktör analizi, faktörler arasındaki ilişkiyi ölçek için korelasyon analizi, bağımsız değişken faktörlerinin bağımlı değiş̧ken faktörleri üzerindeki etkisini belirlemek için regresyon analizi kullanılmıştır. Araştırma bulguları öğrenilmiş çaresizlik ve kariyer planlaması boyutları arasında negatif bir ilişkinin olduğunu göstermektedir. Sonuç olarak, öğrenilmiş çaresizlik boyutlarının işgörenlerin kariyer planları üzerinde etkisinin olduğunu ortaya çıkmıştır. Ayrıca öğrenilmiş çaresizlik-kariyer planlaması ve bu çalışmanın bulgularının gelecekteki çalışmalar üzerinde olası etkilerinin araştırılması tartışılmıştır.

Anabtar Kelimeler: Öğrenilmiş çaresizlik, Kariyer kararı, Kariyer beklentisi, İşgören, Otel işletmeleri

\section{An Analysis of the Relation between Learned Helplessness and Career Planning in Hotel} Businesses

\begin{abstract}
The purpose of this study is to empirically explore the relation between learned helplessness and career planning in hotel businesses in Ankara, Turkey. A total of 84 hotels, ranging from special and boutique type-star to five-star deluxe, responded to questionnaires pooling 405 employees, twenty-one learned helplessness variables, and ten career planning variables. Data were collected by researchers in face-to-face interviews and analyzed with SPSS statistical programs. Structural and convergent validity of the data have revealed with the factor analysis. Factor analysis was performed to identify learned helplessness and career planning dimensions, correlation analysis was employed to test the relation between learned helplessness and career planning dimensions and regression analysis was used to test the effect of learned helplessness dimensions as independent variables on the career planning dimensions as dependent variables. The findings indicate that learned helplessness is negatively associated with career planning. The results indicate learned helplessness dimensions had partially a direct effect on employees' career planning in the hotel businesses. The implications for learned helplessness-career planning and future research implications of this finding are discussed.
\end{abstract}

Key Words: Learned helplessness, Career decision, Career expectation, Employees, Hotel businesses

\section{Atıf İçin / Please Cite As:}

Gönül, B. K. ve Demir, M. (2020). Otel işletmelerinde öğrenilmiş çaresizlik ve kariyer planlaması arasındaki ilişkinin analizi. Manas Sosyal Araştırmalar Dergisi, 9(3), 1648-1662.

Geliş Tarihi / Received Date: 30.01.2019

Kabul Tarihi / Accepted Date: 27.05.2020

\footnotetext{
${ }^{1}$ Doktora Öğrencisi (Ankara Hacı Bayram Veli Üniversitesi, Lisansüstü Eğitim Enstitüsü, Ankara ), kurtulusgonul@gmail.com ORCID: 0000-0001-9805-0337

2 Prof. Dr. - Isparta Uygulamalı Bilimler Üniversitesi, Turizm Fakültesi, Eğirdir, Isparta, mdemir1@gmail.com ORCID: 0000-0002-5878-2717
} 


\section{Giriş}

İnsanlar fizyolojik yaşamı için temel gereksinimleri karşılamak kadar sosyal yaşamını sürdürebilmek amacıyla da ekonomik kaynakları yaratmak ve çalışmak zorundadır. Çalışma yaşamı bireysel ya da örgütsel düzen içinde olabilir. Çeşitli etkenler altında sürdürülen çalışma yaşamı, özellikle örgütsel düzen içinde işgörenleri ve onların beklentilerini, ilişkilerini ve kararlarını şekillendirmekte, olumlu ya da olumsuz sonuçlar ortaya çıkarabilmektedir. Dolayısıyla bu durum işgörenlerin kariyer planlarını da etkileyebilmektedir. İşgörenin çalışma yaşamında karşılaşabileceği olanaklar, sağlayacağı kazanım ve psikolojik tatmin, elde edeceği başarı, ulaşacağı konum ve derece gibi değişkenler kariyer içinde yer alabilir.

İşgörenin kariyer planlamasında örgütsel ortamdan kaynaklı pek çok durumla karşılaşması olağandır. Bunlar olumlu bir etken olarak görülebileceği gibi bir engel, sorun, sıkıntı gibi olumsuz durumda yaratabilmektedir. Bu etkenlerden birisi de işgörenlerin karşlaştığ öğrenilmiş çaresizlik duygusu ve yarattı̆̆ sonuçlarıdır. Örgütsel düzeyde işgörenlerin karşılaştığı sorunlar ve sürekli olarak kontrol edemediği olaylar veya durumlara maruz kalması sonucunda başarma duygusunu kısmen ya da tamamen kaybetmesi, aynı durumların tekrar etmesi durumunda mücadeleden kaçınması öğrenilmiş çaresizlik kapsamında değerlendirilmektedir. Bu çalışma kariyer planlaması ile örgütsel çaresizlik konularını kapsamakta ve araştırmanın temel amacı öğrenilmiş çaresizlik olgusunun işgörenlerin kariyer planlaması ile olan ilişkisi incelemektedir.

\section{İlgili Literatür}

\section{Kariyer Planlamas1}

Kariyer, işgörenlerin çalışma yaşamında karşılaşabileceği olanaklar, elde edebileceği maddi ve manevi kazanımlar, iş tatmini sağlayacak başarı ve mutluluklar, yaşamını kolaylaştırabileceği ekonomik, sosyal ve psikolojik pozisyon ve durumlar olarak ifade edilebilir (Demir, 2014a; Greco ve Kraimer, 2018; Wang ve Wanberg, 2017). Kariyer kavramını yalnızca çalışma yaşamı ile sınırlandırmamak gerekir. İşgörenlerin çalısma yaşamında elde ettiği kazanımlar sosyal yaşamını da belirleyebilmektedir. İçinde yer aldığı topluluklar, etkileşimde bulunduğu insanlar, yatırım yaptığı ekonomik değerler aslında kariyer ile ilgilendirilebilir.

Kariyer tek taraflı bir kavram değildir, bunun hem işgören hem de örgütsel düzeyde karşllığı vardır (Demir, 2014b; Jackson ve Wilton, 2017). Kariyer kavramının kişiye sağladığı deneyim, olgunluk, uzmanlık gibi değerler örgütsel çıktıları da etkileyebilecek önemli hususlardır. Örgüt içinde işgören ne kadar değer kazanırsa, üretim ve hizmete olan katkısı aynı oranda artabilmektedir. Bu nedenle planlamayı üstlenen kişi, örgütsel kariyer planlaması yaparken, hem işgören hem de işletme çıkarları açısından düşünmek durumundadır. İşletmeler arası yaşanan yoğun rekabette fark yaratabilecek en önemli unsurlardan birisi insan kaynakları ve sahip olduğu nitelikleridir. İşyerinde kalifiye, yaratıcı, çözüm odaklı ve motive olmuş işgörenlere sahip işletmeler her zaman daha avantajlı durumda olacaklardır. Kariyer planlaması gibi çeşitli motivasyon araçlarını kullanarak çalışanlarını örgütte tutabilen işletmeler rakiplere göre önemli bir avantaj elde edebilmektedir (Bayraktaroğlu, 2016, s. 165; Budak ve Budak, 2004, s. 611; Demir ve Demir, 2016). $\mathrm{Bu}$ da kariyer planlamasının insan kaynaklarını işletmede tutmak için önemli bir motivasyon aracı olduğunu göstermektedir.

Kariyer öncelikle insana, sonra da işe ilişskin bir kavramdır. İnsana ilişskindir çünkü, insan fizyolojik, psikolojik ve sosyolojik boyutta kişilik, kimlik başarı ihtiyacı, ekonomik ihtiyaç, beklenti, tatmin, motivasyon, sayg1, ilgi, statü, rol, duygu, tutum ve davranış gibi ihtiyaç kümelerinin odağındadır. Kişilerin kimliği ve sosyal konumu onların statüsünü oluşturmasına yardım eder (Hernaus, Pavlovic ve Klindzic, 2019). İşe ilişkindir, çünkü ekonomik ve sosyal kazanımları sağlayabilecek kazanımlar çalışmaya bağlıdır. Kariyer planlaması kariyer yönetiminin bir parçasıdır. Kariyer yönetimi ise, "bireysel olarak veya organizasyonun kariyer sistemleriyle birlikte gerçekleştirilen kariyer planlarının hazırlanması, uygulanması ve izlenmesinin devam eden bir süreci" olarak ifade edilir (Ballakrishnan ve Srividhya, 2007, s. 51). Bu çerçevede kariyer yönetimini bireysel ve örgütsel olarak birçok değişkenin etkilediğini belirtmek mümkündür.

Kariyer yönetiminde örgütsel adalet ve eşitlik işgörenlerin performansını etkileyebildiği gibi işletmede kalma eğilimini, örgütsel bağlllı̆̆nı da olumlu bir şekilde etkileyebilmektedir. İşgörenlerin adalet algılamasının olumlu olması, aynı zamanda bireysel olarak kariyer planlanmasını da olumlu bir şekilde etkileyebilmektedir (Bagdadli ve Gianecchini, 2018; Yu, 2017). Turizm işletmelerinde de görüldüğü gibi 
birçok işletmede yaşanan örgütsel düzeydeki kariyer yönetimi yanlş̧ları işgörenlerin umutsuzluğa kapılmasına, örgüte olan bağıllı̆̆ının azalmasına, bir süre sonra işten ayrılmasına neden olabilmektedir (Tütüncü ve Demir, 2002). Çünkü işgörenler işletmede kalmanın kendi kariyer planlarına bir katk1 sağlamayacağını düşünerek çaresizlik duygusu oluşabilmektedir (Chetana ve Mohapatra, 2017). Bu da işgörenlerde farklı arayışlara, işten ayrılmalara, işletmede kalsa dahi mutsuz ve verimsiz bir şekilde çalışmaya devam etmesine neden olabilmektedir.

İsgörenlerin kariyer kararını etkileyen birçok unsur olabilir. Bu unsurların destekleyici ya da engelleyici özellikler taşıması, işgörenlerin kariyer kararını olumlu ya da olumsuz etkileyebilmektedir. Örgütsel kaynaklı güdüleyici etkenler kişisel özellikli etkenlere göre daha olumlu bir kariyer kararının oluşmasını ortaya çıkarabilmektedir (Martincin ve Stead, 2015; Tütüncü ve Demir, 2002). İşgörenlerin ekonomik, sosyal ve psikolojik tatmin sağlayabileceği olanakların örgütler tarafindan sağlanması, onların kariyer kararını olumlu etkileyen diğer unsurlar olarak değerlendirilmektedir (Di Fabio ve Saklofske, 2014; Gati ve Levin, 2014). Kariyer planlamasında isggörenlerin beklentileri sunulan firsatları doğru değerlendirebilmesiyle de ilişsilidir (Kim, 2016; Lewis, Raque-Bogdan, Lee ve Rao, 2018). Zira yüksek kariyer beklentisine sahip işgörenlerin işletmenin sunduğu firsatları değerlendirememesi durumunda kariyer engelinden bahsetmesi anlamlı olmamaktadır. Bu durumda kariyer kararı da rasyonel olmayacaktır.

\section{Öğrenilmiş Çaresizlik}

İlk olarak sosyal öğrenme alanında çalışan Overmier ve Seligman (1967) tarafından ortaya atılmış olan öğrenilmiş çaresizlik kavramı örgütsel davranış kapsamında farklı boyutlartyla birçok çalışmada incelenmiştir. Öğrenilmiş çaresizlik, bir canlının olumsuz bir durumu davranışlarıyla kontrol edebileceği halde, bunu kontrol etmek için gerekli çabayı göstermeyerek gerekli davranışları yerine getirmediği ya da öğrenmede yetersiz kaldığı durumları açıklamak için kullanılır. Temel olarak öğrenilmiş çaresizlik psikolojinin bir konusudur ve önceki negatif deneyimlerin, daha sonraki öğrenim üzerinde bir etkisi olacağı, organizmayı duyarsız yapacağı gibi bir durumu açıklar (Yüksel ve Özkiraz, 2012, s. 1). Genel olarak öğrenilmiş çaresizlik, kişinin edindiği deneyimlerine göre yaptı̆̆ eylemler ile beklediği sonucun oluşmaması durumunda, kişide aynı eylemleri yapması halinde sonucun değişmeyeceği inancının oluşmasıdır.

Öğrenilmiş çaresizlik teorisinde genel olarak kişi sonucunu kontrol edemediği olumsuz bir durumla karşı karşıya gelmekte ve bunun sonucu oluşan başarısızlığ düşünerek gelecekteki benzer durumlarda, eylem ve çalışmalarında da aynı başarısızlık olacağı duygusuna kapılmaktadır (Costello, 1978; Maier ve Seligman, 2016). Ersever'e (1993) göre, Seligman ve arkadaşlan tarafından, insanların öğrenilmiş çaresizliğinin neden kaynaklandığını bulmak için geliştirilen öğrenilmiş çaresizlik modelinde, bireyin bir durum karşısında gerçekleştirdiği davranışların, durumun sonucu üzerinde kontrolünün olmamasını öğrenmesiyle bireyde oluşacak değişiklikler üzerine eğilmektedir. Modelde, çaresizliği öğrenen bireyde güdüsel, bilişsel ve duygusal alanda üç yetersizlik ortaya çıkar. Güdüsel olarak bireyin karşılaştığı engeller, bilişsel olarak sonucu etkilemedeki kontrol algısının zayıflaması ve duygusal olarak olayları etkileme gücü olmadığına inanması öğrenilmiş çaresizliği ortaya çıkarmaktadır.

Öğrenilmiş çaresizlik yaşantısının giderek, öğrenilmiş çaresizliği ortaya çıkaran koşullarla (nedensonuç ilişkileriyle) bağının zayıflayacağı, tüm koşullara genelleneceği ve yaşamın her alanındaki davranışlara egemen olacağı ileri sürülmektedir. Ancak bu durumun ortaya çıkışı bazı faktörlere bağlıdır. Bu konuda geliştirilen kuramlar insanda "öğrenilmiş çaresizliğin” ortaya çıkışını kontrol eden iki faktörün belirginleştiğini göstermektedir (Alloy, Peterson, Abramson ve Seligman, 1984);

- Kontrol edemediği sonucun kişi için taşıdığı önem,

- Sonuçları kontrol etmesini mümkün kılacak bir şeylerin varllğı konusundaki beklentileri, öğrenilmiş çaresizliğin şiddetinin belirtileri olacaktır.

Modelin yukarıda anlatılan özelliklerine rağmen bazı durumlarda eksiklikleri ortaya çıkmış ve yoğun eleştirilere maruz kalmıştır. Bu eleştirilerin başında kişiler arası farklılıkları değerlendirme dışı bırakması dolayısıyla hangi bireyin çaresizlik davranışı gösterip hangisinin göstermeyeceği konusunun belirsizliği ya da aynı bireyin bir durum karşısında çaresizlik gösterirken, benzer bir durumda neden çaresizlik davranışı göstermediğinin anlaşılamaması olarak gösterilebilir. Bu durum modelin tekrar ele alınarak yeniden formüle edilmesi sonucunu doğurmuştur.

Öğrenilmiş çaresizlik modelinin bireysel ayrılıklar üzerinde durmaması ve benzer olaylar karşısında bazı insanların davranışlarıyla çevreyi kontrol edebileceklerine inanmalarına karşın, bazılarının edemeyeceklerine inandıklarını açılayamaması modele yeni boyutlar getirilmesi gerektiğini ortaya 
çıkarmıştır (Aydın, 1986, s. 10). Bunun yanı sıra özgün modelin sınırlılıkları bazı araştırmacıların öğrenilmiş çaresizliği tekrar incelemelerine neden olmuştur. Bu psikologların çoğu, kontrol edilemeyen olaylara insanların gösterdiği davranışları açıklamak için bilişsel değişkenleri kullanmıştır. Öğrenilmiş çaresizlik modelinde giderilen eksiklikler değerlendirildiğinde "bireysel çaresizlik-evrensel çaresizlik" ilişkisi örgütsel davranış çalışmaları açısından önem taşımaktadır. Buna göre evrensel çaresizlik, başka ortamlardaki davranışları pek etkilemezken bireysel çaresizlik başka ortamlarda çaresizlik davranışın gözlenme olasıllğını arttırıcı etkiye sahip olmaktadır (Hovardaoğlu, 1986, s. 5). Abramson, Seligman ve Teasdale’e (1978) göre, kişilerin hâlihazırda çözülebilir sorunları çözemediklerini düşündükleri durumlar kişisel çaresizlik, alternatif olarak kişilerin ne kendilerinin ne de konuyla ilgili olanların sorunu çözemeyeceğine inandığı durumlar ise evrensel çaresizlik örnekleridir.

Yenilenen modelde ne bireysel çaresizlik ne de yeteneksizlik yüklemesi, çaresizliğin gözlenmesi için tek başına yeterli değildir. Model, bu noktada, çaresizlik davranışı için üçüncü bir koşul daha öngörmekte ve yapılan yüklemenin genellik derecesini önemli bir değişken olarak dikkate almaktadır (Hovardaoğlu, 1986, s. 6). Yenilenen modele göre yeni tahminler dizisi oluşturmaktadır. Çaresiz birey, önce bazı sonuçların ve yanıtların bağımsız olduğunu bulur ve o zaman bunun neden olduğu hakkında bir açıklama yapar. Bu atıf, gelecekteki yanıt-sonuç ilişkileri hakkındaki beklentilerini etkiler ve böylece göreceğimiz gibi kronikliği, genelliliği ve bir dereceye kadar eksikliklerin yoğunluğunu belirler (Abramson, Seligman ve Teasdale, 1978, s. 56). Başka bir ifadeyle, sonuçlan kontrol etme yönünden yeteneksiz olduğuna karar veren birey bu yeteneksizliğinin bir çok durum için geçerli olduğuna inandığı takdirde genellenmiş çaresizlik davranışı gösterecek ve kontrol algısındaki bozulmanın düzeyine bağlı olarak, çaresizliğin ciddiyet derecesi de değişecektir (Hovardaoğlu, 1990, s. 221).

Öğrenilmiş çaresizliğin önemli göstergelerinden birisi işgörenlerin iş yaşamındaki deneyimlerinden edindiğine göre umutsuzluğa kapılması ve yapabileceklerini yapmaması sonucu durumu kabullenmesidir (Chitrakar, 2017; Moreland vd., 2015). Örgüt içinde yanlş̧ uygulamaları değiştirme çabası göstermemesi, gösterse bile başarılı olamayacağı algısının yerleşmiş olması, sorunların sürekli tekrarlaması, başarısız olunan bir görevden sonra kendisine aynı görevin tekrar verilmemesi gibi durumlar bireyin kabullenme duygusu yaşamasına neden olmaktadır (Demir, 2014b). İşgörenin uzun süre aynı pozisyon ve olanaklarla çalısması kabullenme duygusuna kapılarak iş değişikliğine yönelmediğinin de bir göstergesidir.

İşyerinde işgörenlerin başarısını üstlenecek başka çalışanların olduğunun bilinmesi özsaygı kaybının oluştuğunun bir göstergesidir (Boichuk vd., 2014; Degago, 2014). Aynı şekilde işgörenin örgüt içinde göstermiş olduğu çabaya rağmen sürekli engel çıkarılması ve bunun sonucunda işgörenin sorumluluktan kaçmak istemesi çaresizlik olarak değerlendirilmektedir. Diğer yandan örgütsel düzeyde bir görevdeki başarısızlık nedeniyle kendine de pay çıkaran işgörenin öğrenilmiş çaresizlik içinde olduğunu gösterebilmektedir.

Örgüt içinde işgörenler istemese de zaman zaman genel işleyişe ve duruma ayak uydurmak amacıyla sessiz kalarak ortama uyum sağlama davranışı sergileyebilmektedir (Demir, 2014b). Aslında bu durum bir yandan işgörenin konumunu korumaya çalıştığını diğer yandan ise çaresizlik içinde olduğunu açıklayabilir (Degago, 2014; Milliken vd., 2015). İşyerindeki bir kural ve uygulama yanlışa ya da işyerinde iyi ilişkileri olmasını isteyen bir işgören mevcut durumunu kaybetmek için olabileceği gibi bunları değiştirecek gücü olmadığını kabul ederek uyum sağlama davranışı gösterebilmektedir.

Öğrenilmiş çaresizliğin bir başka göstergesi de işgörende yaratmış olduğu değersizlik algısıdır (Chitrakar, 2017; Huang, 2012). İşyerindeki yanlış kural ve uygulamaları düzeltme konusundaki çaba, öneri ve çalışmaları dikkate alınmayan işgören kendisinin örgüt içinde değersiz hissetme duygusuna kapılarak çaresizlik davranışı gösterebilmektedir. Aynı şekilde yapılan her başarısızlıkta herkesin eşit şekilde sorumlu tutulması ya da bireysel olarak yapılan hatanın düzeltilmesi durumunda dahi yönetimin fark etmemesi işgörenlerde öğrenilmiş çaresizlik duygusunun oluşmasına neden olabilmektedir. Bu durum işgörenin motivasyon kaybına neden olmakta ve örgütsel çıktılara da olumsuz etki edebilmektedir.

Literatürden elde edilen bilgiler çerçevesinde araştırmanın hipotezleri aşağıdaki şekilde oluşturulmuştur:

$\mathrm{H}_{1.1}$ - İsgörenlerin öğrenilmiş çaresizlik olarak "kabullenme" tutum ve davranışı kariyer kararını etkiler.

$\mathrm{H}_{1.2-}$ İşgörenlerin öğrenilmiş çaresizlik olarak "özsaygı kaybı” tutum ve davranışı kariyer kararını etkiler.

$\mathrm{H}_{1.3-}$ İşgörenlerin öğrenilmiş çaresizlik olarak “ortama uyum” tutum ve davranışı kariyer kararını etkiler. 
$\mathrm{H}_{1.4-}$ İşgörenlerin öğrenilmiş çaresizlik olarak “değersizlik algısı” tutum ve davranışı kariyer kararını etkiler. $\mathrm{H}_{1.5^{-}}$İşgörenlerin öğrenilmiş çaresizlik olarak "motivasyon kaybı” tutum ve davranışı kariyer kararını etkiler.

$\mathrm{H}_{2.1}$ - İşgörenlerin öğrenilmiş çaresizlik olarak "kabullenme" tutum ve davranışı kariyer beklentisini etkiler.

$\mathrm{H}_{2.2^{-}}$İş̧görenlerin öğrenilmiş çaresizlik olarak "özsayg1 kaybı" tutum ve davranışı kariyer beklentisini etkiler.

$\mathrm{H}_{2.3^{-}}$İşsgörenlerin öğrenilmiş çaresizlik olarak “ortama uyum” tutum ve davranışı kariyer beklentisini etkiler.

$\mathrm{H}_{2.4-}$ İşgörenlerin öğrenilmiş çaresizlik olarak "değersizlik algısı" tutum ve davranışı kariyer beklentisini etkiler.

$\mathrm{H}_{2.5}$ İşgörenlerin öğrenilmiş çaresizlik olarak "motivasyon kaybı" tutum ve davranışı kariyer beklentisini etkiler.

\section{Yöntem}

\section{Araştırmanın Kapsamı ve Sınırlılıkları}

Araştırma öğrenilmiş çaresizlik ile kariyer konusunun örgütsel düzeydeki ilişkisini incelemeye odaklıdır. Araştırmanın temel sınırlılıkları şu şekildedir;

- Araştırma, Ankara ilinde faaliyet gösteren turizm işletme belgeli konaklama işletmeleri ile sinirlidir.

- Araştırma "Öğrenilmiş Çaresizlik Davranışı Ölçeğı" ile "Kariyer Planlaması Ölçeğı̀" değişkenlerinin ölçtüğü niteliklerle sınırlıdır.

\section{Veri Toplama}

Araştırma evreni 181 otel işletmesinden oluşmaktadır. Ancak 140 otel görüşme talebini kabul etmiş ve bunlardan 84'ü anket uygulanması için olumlu yanıt vermiştir. Çalışmayı kabul etmeyen oteller iş yoğunluğu ve önceki araştırmacıların otellerinde gördükleri eksikleri ilgili kurumlara şikâyet etmelerini gerekçe olarak göstermiştir. Anket çalışması yapılan işletmelerin 17'si 5 yıldızlı, 33 'ü 4 yıldızlı, 19'u 3 yıldızlı, 2'si 2 yıldızlı ve 13'ü özel ve butik otellerdir. 2017 yılı Temmuz ayında gerçekleştirilen anket çalışmasında otellere toplam 1200 anket dağıtılmış ve sağlıklı bir şekilde veriler toplanmaya çalışılmıştır. Illk aşamada 446 anketin uygun bir şekilde doldurulduğu görülmüştür. İkinci aşamada yapilan değerlendirme sonucunda 405 anketin güvenilir olduğuna karar verilmiş ve analiz bu sayı üzerinden gerçekleştirilmiştir. Değerlendirme dışı bırakılan anketlerdeki temel sorun tutarsız, rastgele ve tamamen aynı seçeneğin işaretlenmesi ve işgörenlerin zaman bulamamalarından kaynaklı olarak anketleri büyük oranda boş iade etmeleridir.

Araştırmada "Öğrenilmiş Çaresizlik Davranışı Ölçeğı’” ile "Kariyer Planlaması Ölçeği” kullanılmıştır. Öğrenilmiş Çaresizlik Davranışı Ölçeği Abramson ve Seligman (1978), Hiroto ve Seligman (1975), Maier ve Seligman (1976), Boyd (1982)'un çalışmalarından yararlanılarak oluşturulmuştur. Ölçek ortama uyum, motivasyon kaybı, özsayg1, değersizlik algısı ve kabullenme olmak üzere beş boyutta toplanmış toplam 21 sorudan oluşmaktadır. Kariyer Planlaması Ölçeği, Osipow (1987), Demir (2014) ve Demir ve Demir (2016)'in çalışmalarından yararlanılarak oluşturulmuştur. Bu ölçek, kariyer beklentisi, kariyer firsatları ve kariyer kararı olmak üzere üç boyutta toplanmış, toplam 10 sorudan oluşmaktadır. 5'li Likert olarak hazırlanan ölçeğin (1-Kesinlikle katılmıyorum, 2-Katılmıyorum, 3-Kararsızım, 4- Katılıyorum, 5-Kesinlikle katılıyorum) turizm sektöründe en az bir yll çalışmış üniversite öğrencileri ve Antalya'da faaliyet gösteren 5 yıldızlı bir otelde olmak üzere farklı dönemlerde iki kez pilot uygulaması gerçekleştirilmiştir. Buradan elde edilen sonuçlar ICTTR: 3. International Conference on Tourism: Theory, Current Issues and Research konferansında sözlü sunum olarak gerçekleştirilmiş ve yapılan eleştirilere göre tekrar gözden geçilmiş ve gerekli düzeltmeler yapılmıştır.

\section{Verilerin Analizi}

Verilerin analizinde SPSS 22 istatistik paket programı kullanılmıştır. Geçerlilik ve güvenirlik analizlerinin ardından faktör analizi, korelasyon ve regresyon analizi uygulanmıştır. Ulaşılan bulgular 
tablolar yardımılla açıklanmışır. Katılımcıların demografik özelliklerine ilişkin frekans dağılımı yapılmış ancak demografik verilere başka analizler uygulanmadığı için çalışmada yer verilmemiştir.

\section{Bulgular}

Araştırmada öncelikle güvenirlik ve geçerlik analizi yapılmıştır. Elde edilen bulgular verilerin diğer analizler için uygun olduğunu, ölçek yapısının çalışmayı ifade etmek için kabul edilebilir düzeyde gerçekleştiğini ortaya koymaktadır. Tablo 1'de yer aldığı gibi araştırma verilerine genel olarak ve parça düzeyinde uygulanan güvenilirlik ve geçerlik analizi sonuçlarının içsel tutarlılığı da sağlanmıştır. Genel olarak 31 değişkenin Cronbach Alpha değeri= ,91 F değeri= 12,393, p değeri= ,001 ve ortalama değeri (5'li Likert) = 4,09 olarak gerçekleşmiştir. 21 değişkenin bulunduğu Öğrenilmiş Çaresizlik Davranış1 Ölçeğinin güvenilirlik ve geçerlik analizinde, Cronbach Alpha değeri= 85 , F değeri= 4,054, p değeri= ,001 ortalama değeri ( $5^{\prime}$ li Likert $)=4,06$ olarak gerçekleşmiştir. Son olarak 10 değişkenin bulunduğu Kariyer Planlamasında ise, Cronbach Alpha değeri $=, 85, \mathrm{~F}$ değeri= 17,226, p değeri= ,001 ve ortalama değeri (5'li Likert $=4,11$ olarak bulunmuştur. Bulunan bu değerler ölçeklerin güvenilirlik ve geçerlik analizi sonuçlarının içsel tutarlılığını sağladığını göstermektedir.

Tablo 1. Araștırmann Güvenilirlik ve Geçerlik Ölçümleri

\begin{tabular}{lccccc}
\hline & a & F & P & Ort. & n \\
\hline Genel &, 91 & 12,393 &, 001 & 4,09 & 31 \\
\hline Öğrenilmiş Çaresizlik &, 85 & 4,054 &, 001 & 4,06 & 21 \\
\hline Kariyer Planlaması &, 85 & 17,226 &, 001 & 4,11 & 10 \\
\hline
\end{tabular}

\section{Açıklayıcı faktör analizi}

Geçerlik ve güvenirlik analizinden elde edilen bulgular diğer analizlere geçileceğini göstermektedir. Bu nedenle ikinci aşamada hem "öğrenilmiş çaresizlik" hem de "kariyer planlaması" ölçeklerine ilişkin faktör analizi gerçekleştirilmiştir.

\section{Öğrenilmiş çaresizlik ile ilgili bulgular}

"Öğrenilmiş Çaresizlik" davranışı boyutuna ilişkin gerçekleştirilen faktör analizi sonuçları, korelasyon ve regresyon analizleri için uygun olan istatistiksel bulguları ortaya koymuştur $(\alpha=.91$ ve $\mathrm{p}<.001)$. Analiz sonuçlarına göre KMO (Kaiser-Meier Olkin) ölçümünün 0.822 düzeyinde, Bartlett's Test of Sphericity=2921,941 ve bu faktörü oluşturan değişkenler toplam varyansın (AVO) \%58.98'ini açıklamaktadır.

"Öğrenilmiş çaresizlik" ile ilgili faktör analizinde 5 boyut oluşmuştur. Bu boyutlar literatürdeki bilgilere dayanarak "Kabullenme", "Özsayg1 Kaybı", "Ortama Uyum", "Değersizlik Algisı" ve "Motivasyon Kaybı" olarak isimlendirilmiştir. Her bir faktörün içsel tutarlllık ölçüm değerleri "Öğrenilmiş çaresizlik" faktör analizi sonuçları tablosunda sunulmuştur.

Tablo 2'de yer alan birinci faktöre (Kabullenme) ilişkin değişkenler ve analiz sonuçları incelendiğinde 7 değişkenin toplam varyansın \%26,13'ünü (AVO) açıkladığı anlaşılmaktadır. Bu değişkenlerin genel olarak işyerinde bireylerin kabullenme davranışlarını içerdiği ve öğrenilmiş çaresizliğin tepkisizlik şeklinde görüldüğünü ortaya koymaktadır. Kabullenme faktörünün özdeğeri 5,48; standart sapması 4,02 ve ölçek tutum ortalamalarının 4,01 olduğu görülmektedir. Birinci faktörün Cronbach Alpha değeri 0.85 ve anlamllık düzeyi $\mathrm{p}<.001$ olarak gerçekleşmiştir.

İkinci faktör olan "Özsayg1 Kaybı" değişkenleri ve analiz sonuçları; 3 değişkenin toplam varyansın \%10,40’nı açıkladığı görülmektedir. Söz konusu değişkenlerin genel olarak işyerinde çalışan işgörenlerin özsayg1 kaybı davranışlarını kapsadığı ve öğrenilmiş çaresizlik davranışının kişinin öz saygısında bir azalma yarattığ1 şeklinde görüldüğü anlaşılmaktadır. Bu faktörünün özdeğeri 2,19; standart sapması 2,01 ve ölçek tutum ortalamalarının 4,09 olduğu görülmektedir. Bu faktörün Cronbach Alpha değeri: ,83 ve anlamllık düzeyi $\mathrm{p}<, 001$ olarak bulunmuştur.

Üçüncü faktör olan “Ortama Uyum” davranışında 4 değişkenin toplam varyansın \%10,03’ünü açıkladığ1 anlaşılmıştır. Bu değişkenler genel olarak işyerinde çalışan işgörenlerin ortama uyum davranışlarını kapsadığı ve öğrenilmiş çaresizlik davranışının, mevcut şartlara uyma ve duruma göre hareket etmeyi gerektirdiğini açıklamaktadır. İlgili faktörün özdeğeri 2,10; standart sapması 1,92 ve ölçek tutum 
ortalamalarının 4,29 olduğu görülmektedir. Faktörün Cronbach Alpha değeri: ,71 ve anlamlılık düzeyi $\mathrm{p}<, 001$ olarak bulunmuştur.

Son faktör olan "Motivasyon Kaybı"nda 3 değişkenin toplam varyansın \% 5,99’unu (AVO) açıkladığ1 anlaşılmıştır. $\mathrm{Bu}$ değişkenlerin, genel olarak işyerinde işgörenlerin motivasyon kaybı yaşadıkları ve öğrenilmiş çaresizliğin, çalışanlarda motivasyon kaybına neden olduğu ve verim kaybı yaşandığ1 anlaşılmaktadır.

Tablo 2. Ögrgenilmis Caresizlik İle Ilgili Faktör Analizi

\begin{tabular}{|c|c|c|}
\hline & $\begin{array}{l}\text { Faktör } \\
\text { Yükü }\end{array}$ & Ölçüm Değerleri \\
\hline \multicolumn{3}{|l|}{ Faktör 1-Kabullenme } \\
\hline $\begin{array}{l}\text { S9- Yanlış gördüğüm uygulamalar değişmedikçe karşılaşılan problemler gelecekte } \\
\text { de devam eder }\end{array}$ & ,767 & $\begin{array}{r}\text { Özdeğer }=5,48 \\
\text { AVO }(\%)=26,13\end{array}$ \\
\hline $\begin{array}{l}\text { S11- Çok çaba göstersem de yönetimin hakkımdaki düşüncelerinin değişmeyeceğini } \\
\text { sanıyorum. }\end{array}$ & ,741 & $\begin{aligned} \text { Standart Sapma } & =4,02 \\
\text { Ortalama } & =4,01\end{aligned}$ \\
\hline $\begin{array}{l}\text { S21- Zaman zaman neden burada olduğumu soruyorum kendime, nasıl olsa hiçbir } \\
\text { değişmeyecek }\end{array}$ & ,725 & $\begin{array}{r}\alpha=, 85 \\
\mathrm{p}=, 001\end{array}$ \\
\hline S22-İşyeri değiştirmek de çözüm değil, her yerde aynı sorun devam edecek & ,689 & \\
\hline S15- Bir görevde başarısız olmuşsam benzer görevler bir daha verilmez. & 662 & \\
\hline $\begin{array}{l}\text { S17- Uzun süredir aynı iş ve pozisyonda çalışıyorsam işle ilgili fazla yeteneğim } \\
\text { olmadığı içindir. }\end{array}$ & ,658 & \\
\hline $\begin{array}{l}\text { S16- Uzun süredir aynı iş ve pozisyonda çalışıorsam yeterli deneyime sahip } \\
\text { değilimdir }\end{array}$ & ,614 & \\
\hline \multicolumn{3}{|l|}{ Faktör 2- Özsayg1 Kayb1 } \\
\hline S19- İşyerinde sizin başarınızı sahiplenecek çok kişi vardır. & ,891 & Özdeğer $=2,19$ \\
\hline S18- İşyerinde siz ne kadar çaba gösterseniz de karşınıza bir engel çıkar & 873 & $\operatorname{AVO}(\%)=10,46$ \\
\hline S6- Bir görevdeki başarısızlıkta kendi payım olduğunu düşünürüm & ,789 & $\begin{aligned} \text { Standart Sapma } & =2,01 \\
\text { Ortalama } & =4,09 \\
\alpha & =, 83 \\
\mathrm{p} & =, 017\end{aligned}$ \\
\hline \multicolumn{3}{|l|}{ Faktör 3- Ortama Uyum } \\
\hline $\begin{array}{l}\text { S1-İnsanların samimi olmayan davranışları benim de performansımı olumsuz } \\
\text { etkiler. }\end{array}$ & ,620 & $\begin{array}{r}\text { Özdeğer }=2,10 \\
\text { AVO }(\%)=10,03\end{array}$ \\
\hline S2-Çalışanların dürüst ve doğru olmayan tutum ve davranışlarını değiştiremem & 699 & Standart Sapma $=1,92$ \\
\hline S3-İşyerindeki bir kural ve uygulama yanlışsa sizde uymak zorundasınız & ,676 & Ortalama $=4,29$ \\
\hline $\begin{array}{l}\text { S14-İsyerinde iyi ilişkilerin olmasını istiyorsan herşeyi görmeyecek, duymayacak ve } \\
\text { söylemeyeceksin }\end{array}$ & 687 & $\begin{array}{r}\alpha=, 71 \\
\mathrm{p}=, 001 \\
\end{array}$ \\
\hline \multicolumn{3}{|l|}{ Faktör 4-Değersizlik Algısı } \\
\hline $\begin{array}{l}\text { S4-İşyerindeki yanlış kural ve uygulamaları düzeltme konusundaki önerilerim } \\
\text { dikkate alınır }\end{array}$ & ,689 & $\begin{aligned} \text { Özdeğer } & =1,33 \\
\text { AVO }(\%) & =6,35\end{aligned}$ \\
\hline S10- Her başarısızlıkta genelde işi yapan kişi sorumlu tutulur & ,636 & Standart Sapma $=1,93$ \\
\hline $\begin{array}{l}\text { S20- İşyerinde herkes sorumluluğunu yerine getirmediği sürece sizin çabanız } \\
\text { boşunadır }\end{array}$ & 672 & $\begin{array}{r}\text { Ortalama }=4,14 \\
\alpha=, 72\end{array}$ \\
\hline S26-Hatalarımı düzeltsem de kimse farkında olmayacaktır & ,539 & $\mathrm{p}=, 001$ \\
\hline \multicolumn{3}{|l|}{ Faktör 5 - Motivasyon Kayb1 } \\
\hline S27-İşletmedeki ödüllendirme sistemi performanstan ziyade motivasyon odaklıdır & ,581 & Özdeğer $=1,25$ \\
\hline S28- İşletmedeki kişiler arası ilişkiler geleceğinizi belirler & ,772 & $\operatorname{AVO}(\%)=5,99$ \\
\hline S29- Bir işi görevim olmadığı halde yerine getirsem de fark edileceğini sanmıyorum. & 814 & $\begin{aligned} \text { Standart Sapma } & =1.58 \\
\text { Ortalama } & =4,13 \\
\alpha & =, 74 \\
\mathrm{p} & =, 001\end{aligned}$ \\
\hline
\end{tabular}

\section{Kariyer Planlaması ile İlgili Bulgular}

Araştırmada ikinci olarak "Kariyer Planlaması" boyutuna ilişkin faktör analizi gerçekleştirilmiştir. Analiz sonuçlarına göre KMO (Kaiser-Meier Olkin) ölçümünün 0.873 düzeyinde, Bartlett's Test of Sphericity $=1672,978$ ve bu faktörü oluşturan değişkenler toplam varyansın (AVO) \%53.79'unu açıklamaktadır.

"Kariyer Planlaması" ile ilgili faktör analizinde 3 boyut oluşmuştur. Literatürdeki bilgiler sşığında "Kariyer Kararı" ve "Kariyer Beklentisi" olarak isimlendirilen faktör gruplarının içsel tutarlılık ölçüm değerleri "Kariyer Planlaması" ile ilgili faktör analizi (Tablo 3) tablosunda verilmiştir. 
Tablo 3. Kariyer Planlamasi İle İlgili Faktör Analizi

\begin{tabular}{|c|c|c|}
\hline Faktör 1-Kariyer Kararı & Faktör Yükü & Ölçüm Değerleri \\
\hline S.35 Kariyerime bu işletmede devam etmeyi düşünüyorum. & ,658 & Özdeğer $=4,97$ \\
\hline S.39 İşimden ayrılmayı düşünmüyorum. & ,767 & $\mathrm{AVO} \%=35,52$ \\
\hline S.40 Yönetim kendimi geliştirmemi destekliyor. & ,741 & Standart Sapma $=3,04$ \\
\hline S.45 Bu işletmedeki kariyerimle ilgili uzun vadeli planlarım var. & 725 & Ortalama $=4,07$ \\
\hline $\begin{array}{l}\text { S. } 46 \text { Bilgi ve yeteneğim kariyerimi bu işletmede sürdürmem için } \\
\text { önemsenmektedir. }\end{array}$ & 689 & $\begin{array}{r}\alpha=, 77 \\
p=, 033\end{array}$ \\
\hline $\begin{array}{l}\text { S.48 Daha iyi pozisyonda iss bulsam bile karar vermeden önce } \\
\text { yöneticilerimle değerlendiririm. }\end{array}$ & 662 & \\
\hline \multicolumn{3}{|l|}{ Faktör 2-Kariyer Beklentisi } \\
\hline S.34 İnsanlar her yaptı̆̆ işle ilgili beklenti içerisindedir. & ,891 & Özdeğer $=1,43$ \\
\hline S.36 Sabredersem hak ettiğim yere geleceğime inanıyorum. & 873 & $\mathrm{AVO} \%=10,25$ \\
\hline $\begin{array}{l}\text { S. } 44 \text { Hak ettiğim yere gelebilmek için zaman ihtiyacım olduğunu } \\
\text { düşüyorum. }\end{array}$ & ,789 & $\begin{aligned} \text { Standart Sapma } & =2,27 \\
\text { Ortalama } & =4,05\end{aligned}$ \\
\hline S. 49 Kariyerimle ilgili hep iyi şeyler olacağını umuyorum. & ,717 & $\begin{array}{r}\alpha=, 75 \\
p=, 024\end{array}$ \\
\hline
\end{tabular}

Birinci faktör olan "Kariyer Kararı" değişkenleri toplam varyansın \%35,52'sini açılamakta ve bu değişkenlerin genel olarak işgörenlerin mevcut işletmelerinde çalş̧maya devam etmek istedikleri (S.35, S,39 ve S.45) ve işletmelerin işgörenlerinin kişisel gelişimlerini destekleyerek (S.40) çalıssanlarıyla uzun süreli çalışmayı düşündükleri hissi vermektedirler. Bu durum ölçek tutum ortalamasına 4,07 olarak yansımıştır. "Kariyer Kararı" faktörünün özdeğeri 4,97; standart sapması 4,02 hesaplanmıştır. Ayrıca, bu ilk faktörün Cronbach Alpha değeri 0,77, anlamllık düzeyi $\mathrm{p}<, 033$ olarak gerçekleşmiştir.

Kariyer planlaması ile ilgili faktör analizinin ikinci faktörü olan "Kariyer Beklentisi" 4 değişken ile açıklanmıștır. Bu değișkenler toplam varyansın \%10,25 (AVO)'ini açılamaktadır. Ölçek tutum ortalaması ise 4,05 olarak bulunmuştur. Anket çalışmasına katılan işgörenlerin, bir önceki faktör ile paralel olarak işyerleriyle ilgili olumlu kariyer beklentisi içinde oldukları görülmektedir. Bu sebeple kariyerler planlamalarını mevcut işletmeye göre yaptıkları düşünülebilir. Bu faktörün özdeğeri 1,43; standart sapması 2,27 olarak bulunmuş, Cronbach Alpha değeri 0,75 ve anlamll1ık düzeyi $\mathrm{p}<, 024$ olarak gerçekleşmiştir.

\section{Korelasyon Analizi}

Araştırmada bağımsız ve bağımlı değişkenlerin oluşturduğu faktörlerin arasındaki ilişkiyi belirlemek amacıyla korelasyon analizi gerçekleştirilmiştir. "Kabullenme", "Özsaygı Kaybı", "Ortama Uyum", "Değersizlik Algısı" ve "Motivasyon Kaybı" olarak gruplanan öğrenilmiș çaresizlik değișkenlerinden oluşan faktörler ile "Kariyer Kararı" ve "Kariyer Beklentisi" olarak gruplanan kariyer planlaması bağımlı değişkenlerini tanımlayan faktörler arasındaki ilişkinin korelasyon analizi değerleri tablo 4'de verilmiştir.

Tablo 4. Korelasyon Analiz̨i Sonuclar

\begin{tabular}{lcccccc}
\hline \multicolumn{1}{c}{ Değişkenler } & 1 & 2 & 3 & 4 & 5 & 6 \\
\hline 1-Kabullenme & 1 & & & & \\
2- Özsayg1 Kayb1 & $.218^{* *}$ & 1 & & & \\
3- Ortama Uyum & $.377^{* *}$ &, $255^{* *}$ & 1 & & \\
4- Değersizlik Alg1s1 & $.426^{* *}$ &, $129^{* *}$ &, $332^{* *}$ & 1 & & \\
5- Motivasyon Kayb1 & $.260^{* *}$ &, 056 &, $379^{* *}$ &, $350^{* *}$ & & \\
6- Kariyer Karar1 & $.611^{* *}$ &,$- 540^{* *}$ &,$- 316^{* *}$ &,$- 562^{* *}$ &,$- 578^{* *}$ & 1 \\
7- Kariyer Beklentisi & $.766^{* *}$ &,$- 554^{* *}$ &,- 441 &,$- 682^{* *}$ &,$- 579^{* *}$ &, $575^{* *}$ \\
\hline
\end{tabular}

Pearson korelasyon (2 yönlü), ${ }^{*} \mathrm{p}<.05 * * \mathrm{p}<.01$

\section{Kabullenme}

Öğrenilmiş çaresizlik değişkenlerinden olan "Kabullenme" ile "Kariyer Kararı" arasında negatif yönlü orta düzeyde anlamlı bir ilişkinin olduğu görülmektedir $(\mathrm{r}=-.611 ; \mathrm{p}<.01)$. Aynı şekilde "Kabullenme" faktörü diğer bağımlı değișkenlerin olușturduğu faktörler ile benzer bir ilișkisi söz konusudur. "Kabullenme" faktörü ile "Kariyer Beklentisi" faktörü arasında negatif yönlü yüksek düzeyde $(r=-.766$; $\mathrm{p}<.01)$ anlamlı bir ilişkinin olduğu görülmektedir. Bu durum, işgörenlerde öğrenilmiş çaresizlik kabullenme 
algısının artması, kariyer planlamasına yönelik "Kariyer Kararı" ve "Kariyer Beklentisi” düşüncesini azaltmaktadır.

\section{Özsayg1 Kaybı}

"Özsayg1 Kaybı" ile "Kariyer Kararı" arasında negatif yönlü orta düzeyde anlamlı bir ilişki oluşmuştur $(\mathrm{r}=-540 ; \mathrm{p}<.01)$. Bu faktör paralel bir biçimde "Kariyer Beklentisi" ile de negatif yönlü orta düzeyde anlamlı bir ilişski içindedir ( $\mathrm{r}=-.554 ; \mathrm{p}<.01)$. Bu bulgular dahilinde öğrenilmiş çaresizlikte özsayg1 kaybı artan kişilerin kariyer planlamasında, kariyer kararı ve kariyer beklentisi azalmaktadır.

\section{Ortama Uyum}

Öğrenilmiş çaresizlik faktörlerinden biri olan "Ortama Uyum” davranışı ile kariyer planlama değişkenleri arasında genel olarak negatif yönlü orta düzeyde anlamlı ilişki bulunmuştur. "Ortama Uyum" davranışı ile "Kariyer Kararı" arasında negatif yönlü orta düzeyde anlamlı bir ilişki vardır $(r=-.316 ; p$ $<.01)$. Benzer şekilde "Kariyer Beklentisi ile de yine orta düzeyde negatif anlamlı bir ilişki içindedir $(\mathrm{r}=$ $.441 ; \mathrm{p}<.01)$. Sonuç olarak, işgörenler oluşan olumsuz durum ve olaylara bir katkısının olamayacağı düşüncesiyle pasifleşerek ortama uyum sağlamaya başladıkça kariyer kararı ve kariyer beklentisi konularında olumsuzluklar yaşamaktadıllar.

\section{Değersizlik Alg1sı}

İşgörenin öğrenilmiş çaresizlik içinde olmasıyla oluşacak olan kendini değersiz görme durumunda kariyer kararında olumsuz etkiler olacaktır. İki faktör arasında negatif yönlü orta düzeyde anlamlı ilişki tespit edilmiştir $(\mathrm{r}=-.562 ; \mathrm{p}<.01)$. Bir başka kariyer planlaması faktörü olan "Kariyer Beklentisi" ise benzer şekilde negatif yönlü orta düzey anlamlı bir ilişki içindedir $(r=-.682 ; \mathrm{p}<.01)$. Bu nedenle işgörenin değersizlik algısı arttıkça bağlı olduğu işyerindeki kariyeriyle ilgili olumlu değerlendirmesi azalmaktadır.

\section{Motivasyon Kayb1}

Öğrenilmiş çaresizliğin bir başka faktörü olan "motivasyon kaybı" ile kariyer planlaması faktörleri arasında da genel olarak negatif bir ilişki söz konusudur. "Motivasyon kaybı" faktörü ile "kariyer kararı" faktörü arasında negatif yönlü ve orta düzeyde anlamlı bir ilişki vardır $(r=-.578 ; \mathrm{p}<.01)$. Bu faktöre yakın bir şekilde "kariyer beklentisi" faktörü de negatif yönlü ve orta düzeyde anlamlı bir ilişki ortaya çıkmışır $(\mathrm{r}=-.579 ; \mathrm{p}<.01)$. Bulgular işgörenlerde motivasyon kaybı artmasına karşıı kariyer planlamasına yönelik kariyer kararı ve kariyer beklentisinin azaldığını göstermektedir.

\section{Regresyon Analizi}

Korelasyon analizi ile belirlenen faktörler arasındaki ilişki, tek başına çalışmanın amacına uygun sonuçlar ortaya çıkarmada yeterli olamayabilir. Bu ilişkilerin varlığ kadar bağımlı değişkenlerin bağımsız değişkenlerden etkilenip etkilenmediği, etkileniyor ise düzeyinin ne olduğu da önemlidir. Bu nedenle bağımlı değişkenler ile bağımsız değişkenlerin oluşturduğu faktör gruplarına yönelik regresyon analizi gerçekleştirilmiştir.

Tablo 5. Kariyer Kararna İliskkin Regresyon Analiz̨i Sonuçlan

\begin{tabular}{|c|c|c|c|c|c|}
\hline \multirow[t]{2}{*}{ Değişkenler } & \multicolumn{2}{|c|}{ Standartlaştırılmamış katsayılar } & \multirow{2}{*}{$\frac{\text { Standartlaştırılmış katsayılar }}{\beta}$} & \multirow[t]{2}{*}{$\mathrm{t}$} & \multirow{2}{*}{$\bar{p}$} \\
\hline & B & St. hata & & & \\
\hline Sabit & ,352 & 215 & & 11,641 & 002 \\
\hline 1-Kabullenme & ,354 & ,036 & ,401 & 9,792 &, 001 \\
\hline 2-Özsayg1 Kayb1 & 057 & 028 & 075 & 2,030 & 043 \\
\hline 3- Ortama Uyum & 041 & 038 & 021 & ,138 & 970 \\
\hline 4-Değersizlik Algıs1 & ,352 & 043 & ,336 & 8,235 &, 001 \\
\hline 5-Motivasyon Kaybı & 141 & 043 & 133 & 3,234 & 001 \\
\hline
\end{tabular}

Bireylerin "Kariyer Kararı" üzerinde öğrenilmiş çaresizlik değişkenlerinin oluşturduğu faktörlerin etkisinin olup olmadığını belirlemek amacıyla regresyon analizi uygulanmıştır. Regresyon analiz sonuçları tablo 5'de görüldüğ̈̈ gibi "Kariyer Kararı" bağımlı değişkenler faktörünü "Kabullenme", "Değersizlik Alg1s1", "Motivasyon Kaybı" ( $\mathrm{t}>1,80 ; \mathrm{p}<.01)$ ve "Özsayg1 Kaybı" ( $\mathrm{t}>1,80 ; \mathrm{p}<.05)$ faktörleri etkilerken "Ortama Uyum”, ( $\mathrm{t}<1,80 ; \mathrm{p}>.05)$ faktörünün etkisinin olmadığ1 görülmektedir. 
Tablo 6. Kariyer Beklentisine İliskin Regresyon Analizi Sonuclar

\begin{tabular}{|c|c|c|c|c|c|}
\hline \multirow[b]{2}{*}{ Değişkenler } & \multicolumn{2}{|c|}{$\begin{array}{l}\text { Standartlaştırılmamıs } \\
\text { katsayılar }\end{array}$} & \multirow{2}{*}{$\begin{array}{c}\text { Standartlaştırılmış } \\
\text { katsayılar }\end{array}$} & \multirow[b]{2}{*}{$\mathbf{t}$} & \multirow[b]{2}{*}{$\mathbf{P}$} \\
\hline & B & St. hata & & & \\
\hline Sabit &, 354 & 244 & & 10,43 & ,015 \\
\hline 1-Kabullenme &, 550 & 041 &, 555 & 13,412 &, 000 \\
\hline 2-Özsayg1 Kayb1 & ,226 & 049 & ,191 & 4,577 &, 000 \\
\hline 3- Ortama Uyum &,- 023 & ,032 &,- 027 &,- 724 & ,469 \\
\hline 4-Değersizlik Alg1s1 & ,070 & 049 & 060 & 1,441 & ,150 \\
\hline 5-Motivasyon Kayb1 & 079 & 043 & 073 & 2,009 & ,038 \\
\hline
\end{tabular}

Tablo 6'da çıkan sonuçlara göre, bireylerin "Kariyer Beklentisi" üzerinde öğrenilmiş çaresizlik değişkenlerinin etkisine yönelik regresyon analizi sonuçlarında "Kabullenme", "Özsayg1 Kaybı" (t>1,80; $\mathrm{p}<, 01)$ ve "Motivasyon Kaybı" faktörlerinin "Kariyer Beklentisi” üzerinde etkisinin olduğu görülmektedir. Buna karşın, "Ortama uyum" ve "Değersizlik Algısı" faktörlerinin $(t<1,80 ; p>, 05)$ ise etkisi bulunmamaktadır.

Hipotez test analiz sonuçları Tablo 7'de yer almaktadır. Buna göre, toplam 10 hipotezden 7'sinin desteklendiği 3'ünün ise desteklenmediği görülmektedir. Ulaşılan sonuçlar genel olarak değerlendirilmiş ve literatürle karşılaştırılarak tartışma bölümünde açıklanmıştır.

Tablo 7. Arasstrmanin Hipotez Sonuclarn

\begin{tabular}{|c|c|c|c|}
\hline Hipotezler & $\mathrm{t}$ & $\mathrm{p}$ & Sonuç \\
\hline $\begin{array}{l}\mathrm{H}_{1.1} \text { - İşgörenlerin öğrenilmiş çaresizlik olarak "kabullenme" } \\
\text { tutum ve davranışı kariyer kararını etkiler. }\end{array}$ & 9,$792 ; \quad \mathrm{t}>1,80$ &, $001 ; \mathrm{p}<, 01$ & Desteklendi \\
\hline $\begin{array}{l}\mathrm{H}_{1.2} \text { - İşgörenlerin ögrenilmiş çaresizlik olarak "özsayg1 } \\
\text { kaybı" tutum ve davranışı kariyer kararını etkiler. }\end{array}$ & 2,$030 ; \mathrm{t}>1,80$ &, $043 ; \mathrm{p}<, 05$ & Desteklendi \\
\hline $\begin{array}{l}\mathrm{H}_{1.3}-\text { İşgörenlerin öğrenilmiş çaresizlik olarak "ortama } \\
\text { uyum" tutum ve davranışı kariyer kararını etkiler. }\end{array}$ &, $138 ; \mathrm{t}<1,80$ &, $970 ; \mathrm{p}>, 05$ & Desteklenmedi \\
\hline $\begin{array}{l}\mathrm{H}_{1.4-} \text { İşgörenlerin öğrenilmiş çaresizlik olarak "değersizlik } \\
\text { algısı" tutum ve davranıșı kariyer kararını etkiler. }\end{array}$ & 8,$235 ; \mathrm{t}>1,80$ &, $001 ; \mathrm{p}<, 01$ & Desteklendi \\
\hline $\begin{array}{l}\mathrm{H}_{1.5} \text { - İşgörenlerin ögrenilmiş çaresizlik olarak "motivasyon } \\
\text { kaybı" tutum ve davranışı kariyer kararını etkiler. }\end{array}$ & 3,$234 ; \mathrm{t}>1,80$ &, $001 ; \mathrm{p}<, 01$ & Desteklendi \\
\hline $\begin{array}{l}\mathrm{H}_{2.1} \text { - İsgörenlerin öğrenilmiş çaresizlik olarak "kabullenme" } \\
\text { tutum ve davranışı kariyer beklentisini etkiler. }\end{array}$ & 13,$412 ; \mathrm{t}>1,80$ &, $000 ; \mathrm{p}<, 01$ & Desteklendi \\
\hline $\begin{array}{l}\mathrm{H}_{2.2-} \text { İşgörenlerin öğrenilmiş çaresizlik olarak "özsayg1 } \\
\text { kaybı" tutum ve davranışı kariyer beklentisini etkiler. }\end{array}$ & 4,$577 ; \mathrm{t}>1,80$ &, $000 ; \mathrm{p}<, 01$ & Desteklendi \\
\hline $\begin{array}{l}\mathrm{H}_{2.3} \text { - İsgörenlerin öğrenilmiş çaresizlik olarak "ortama } \\
\text { uyum" tutum ve davranışı kariyer beklentisini etkiler. }\end{array}$ &,$- 724 ; \mathrm{t}<1,80$ &, $469 ; \mathrm{p}>, 05$ & Desteklenmedi \\
\hline $\begin{array}{l}\mathrm{H}_{2.4} \text { - İşgörenlerin öğrenilmiş çaresizlik olarak "değersizlik } \\
\text { alg1s1" tutum ve davranışı kariyer beklentisini etkiler. }\end{array}$ & 1,$441 ; \mathrm{t}<1,80$ &, $150 ; p^{>}>, 05$ & Desteklenmedi \\
\hline $\begin{array}{l}\mathrm{H}_{2.5} \text { - İşgörenlerin öğrenilmiş çaresizlik olarak "motivasyon } \\
\text { kaybı" tutum ve davranışı kariyer beklentisini etkiler. }\end{array}$ & 2,$009 ; \mathrm{t}>1,80$ &, $038 ; \mathrm{p}<, 05$ & Desteklendi \\
\hline
\end{tabular}

Tartışma

İşgörenlerin çalışma yaşamında karşlaş̧ıkları sorunların çözüme kavuşturulması, iş performansını etkileyebildiği gibi çalışma yaşamı kalitelerini de olumlu etkileyebilmektedir (Demir, 2011). Aksi yönde bir algının oluşması, diğer bir deyişle yanlış uygulamalar düzeltilmediği, sorunlar çözülmediği ya da bu yönde bir algının oluşması bireysel performansı etkileyebildiği gibi olumsuz örgütsel sonuçları da ortaya çıkarmaktadır. Değişmeyen yönetim yaklaşımı, işgörenin gördüğü olumsuzlukların içinde çalışması ve yönetimin müdahale etmemesi konusunda sürekli kendini sorgulamas1, aynı şekilde bunun sektörün genel bir sorunu şeklinde algılanması bir bakıma kabullenme durumunu ortaya çıkarmaktadır. İşgörenin işyerindeki algıladığı olumsuz uygulamalar, durumsal ilişkiler, üretim süreçleri ve çalışma koşulları, eğitim ve gelişim olanaklarının yetersizliğini kabullenerek çalışma yașamına devam etmesi, artık tüm bu hususların kabullenildiğinin bir göstergesidir. Kabullenme durumunun artması işgörenin kariyer kararını etkilediği regresyon analizi sonuçlarıyla belirlenmiştir. Bu etkinin ilişki yönünün negatif olmasıyla (korelasyon analizi sonuçlarına göre), kabullenme algısı arttıkça işgörenin kariyer kararını aynı işletmede devam ettirmesine 
yönelik tutumu azalmaktadır (Gönül, 2018). İşgörenin "kabullenme" olarak yaşadığ1 öğrenilmiş çaresizlik durumu yalnızca onun işletmedeki kariyer kararını değil, aynı zamanda kariyer beklentisi ve kariyer olanaklarını değerlendirme tutumunu da olumsuz bir şekilde etkilemektedir.

Öğrenilmiş çaresizlik boyutu olarak belirlenen özsayg1 kaybı algısının artması işgörenlerin kariyer beklentisi, kariyer kararı ve kariyer olanaklarını değerlendirme tutumunu olumsuz bir şekilde etkilemektedir. Örgüt içinde bir bireyin başarısını başkalarının sahiplenmesi kadar başkalarının hatalarına ortak olunması özsaygının kaybedilmesinin bir göstergesidir. Bu durumda işgören örgüt içinde sürekli engellendiği duygusuna kapilarak kariyerine yönelik kararı tekrar düşünmek durumunda kalabilmektedir (McMullen ve Krantz, 1988; Tiggemann ve Winefield, 1984). İşgörenin işletmede kaldığ1 sürece kendisini değerli, yeterli ve önemli hissetmemesi, yani özsaygı eksikliği yaşaması ardı ardına gelen hatalara, hata beklentisine, iletişim sorununa, kendine güven kaybına ve performans düşüklügüne neden olabilecektir.

Çalışma yaşamında bireyler olumlu ya da olumsuz algılanabilecek durumlara karşı önce tepkisiz davranarak bir süre sessiz kalmay1 tercih edebilmektedir (Demir ve Demir, 2012). Bu sessiz kalma durumu olumsuz gelişmeler karşısında süreklilik gösterirse, bireyin kendi çıkarlarını, durumunu ve geleceğini düşünerek ortama uyum sağlaması kaçınılmaz olabilmektedir. İşgörenlerin çalışma arkadaşlarının samimiyetsiz davranışlarına tepki verememesi, hatta onların yanlış olduğunu bilmesine rağmen aynı ortamda bulunması, başkalarının sübjektif kurallar ortaya koyması, yaşananları, uygulananları, iş ilişsilerini ve iletişimi olumsuzlaştıran her şeyi görmeyip, duymayıp sessiz kalma tutum ve davranışı sergilemesi "ortama uyum sağlama" olarak ifade edilmektedir. Olumsuzlukların olduğu bir çalışma ortamında bireyin ortama uyum sağlaması öğrenilmiş çaresizlik boyutlarından birisidir. Ancak bu durum işgörenin çalışma yaşamını etkileyen diğer öğrenilmiş çaresizlik faktörlerinin aksine bireyin kariyer planlamasını olumsuz etkilememektedir. Çünkü işgören kariyer beklentisi, kariyer kararı ve kariyer olanaklarını değerlendirmek için bilinçli olarak ortama uyum sağlama davranışı içinde olabilmektedir. işgörenin değersizlik algısına kapılması hem kendi sosyal yaşamı hem de çalısma yaşamında birtakım sorunların ortaya çıkarabilmektedir. Örgüt içinde değerli olduğunu hisseden işgören ile aynı algıya sahip olmayan işgörenin işe olan tutumu, ilişkileri, üretim ve hizmet performansı birbirinden farklı olacaktır (Karlsson, 2012; Lawrence ve Crocker, 2009). İsgörenin değer alg1sı yüksekliği örgütsel bağlllı̆̆ının artmasına da olanak sağlayacaktır. Örgüt içinde üretim ve hizmet sunumunun etkin bir şekilde yürütülmesinde işgörene verilen değerin olumlu bir etkisinin olacağı kesindir. Bu durum özellikle turizm işletmelerinde doğrudan müşteri ile etkileşim halinde olan işgörenlerin iş çıktılarına etkisi açısından daha fazla önemli hale gelmektedir. Örgüt içinde değer bulduğuna inanan işgörenin kariyerine yönelik "devam etme" kararında etkili olan bu tür algılar, eğer "değersizlik" alg1sına dönüşürse "Kariyer Beklentisini”" etkilememektedir. Diğer bir deyişle, değersizlik alg1sı işgöreni kariyer beklentisi içine sokmayacaktır. Ancak değersizlik alg1sı işgöreni tamamen örgütten koparmayacaktır. İş alternatifi bulunmadığ1 sürece, örgütün sunacağı bir kariyer olanağı söz konusu olursa işgören bunun da değerlendirme eğiliminde olabilmektedir.

Öğrenilmiş çaresizliğin bir başka faktörü olan motivasyon kaybı çalışma yaşamında bireysel, örgütsel ve turizm sektörü açısından iş çıktılarını etkilediği gibi ilgili tarafların plan, beklenti ve kararlarını da etkileyebilmektedir. İşgörenin örgüt içinde yaşadığı motivasyon kaybının yalnızca bireysel sonuçları olmayacaktır. $\mathrm{Bu}$ durum hem kendi geleceğini hem de örgüt performansını olumsuz bir şekilde etkileyecektir. Motivasyon kaybı bireysel beklentileri, örgütsel hedefleri ve ortak çıkarlar üzerinde de olumsuz etkiler yaratır (Baum, 2015; Southiseng ve Walsh, 2011). İsgörenin örgüt içinde kariyer hedefine yönelik kararı, kariyer beklentisi ve kariyer olanaklarını değerlendirmesine yönelik tüm durumlar üzerinde motivasyon kaybının yarattığı etki, örgüt yönetimi tarafindan da olumsuz sonuçlar ortaya koyacaktır.

\section{Sonuç ve Öneriler}

Öğrenilmiş çaresizlik konusunun gerek bireysel gerekse örgütsel düzeyde ne kadar önemli olduğu araştırma bulgularıyla ortaya konulmuştur. İşgörenlerin kariyer kararı, kariyer beklentisi ve kariyer olanaklarını değerlendirmesi yalnızca kendilerine bağlı bir konu değildir. Bu konuda işgörenin bireysel yetenek, yetkinlik ve performans1 kadar örgütün olanaklar1, hedefleri ve ürün üretim-hizmet sunum potansiyeli de belirleyici olabilmektedir. Çünkü kariyer planlaması ve yönetimi her iki tarafin ortak değerleri ve hedefleri sonucunda yönetilebilir.

İşletmelerin turizm sektöründe başarılı olmasında insan kaynakların rolü oldukça fazladır. Diğer bir deyişle, her örgüt insan kaynaklarının nitelikleri kadar değerlidir. İşgörenlerin iş çıktılarına doğrudan etki etmesi nedeniyle örgüt içinde sosyo-psikolojik etkenler önemli hale gelir. İşgörenin işe odaklanmasını sağlayacak örgüt içi dinamikler hem bireysel hem de örgütsel hedeflere ulaşmada belirleyici bir oynar. 
Dolayısıyla örgütlerin işgörenden elde edeceği en yüksek verimin bir ölçüde yönetsel karar ve uygulamalara bağlı olduğu gerçeğidir. İşgörenin tutum ve davranışının olumlu bir şekilde örgüte değer katacak ölçüde oluşması, beklenen iş çıktılarına önemli bir kaynaktır.

Öğrenilmiş çaresizlik boyutu olarak değerlendirilen kabullenme durumu, işgörenin çabasına, emeğine, sorumluluğuna rağmen ters giden olumsuz şeylerin değişmemesi karşısında geri çekilmesidir. Belirli iş kurallarını, düzenlemelerini, örgüt kültürünü göz ardı ederek hata ve yanlışlarda işgörenin uyarılarını dikkate almamak, örgüt içinde duyarlı işgörenlerin ne yaparsa yapsin emeğinin boşa gideceği alg1sını yaratacaktır. Bu durumda işgörenin kariyer kararı üzerinde "kabullenme" faktörü öğrenilmiş çaresizlik etkili olacak ve işgöreni başka iş arayışına yöneltebilecektir. Bu durum yalnızca işgörenin örgütteki kariyer kararı ile sınırlı değildir. Aynı zamanda o örgütteki kariyer beklentisinin oluşmaması bir süre sonra işten ayrılmayı da getirecektir.

Diğer yandan işgörenlerin özsaygısını kaybetmesi öğrenilmiş çaresizliği bir başka durumunu ortaya koyar. İşerinde gösterilen başarıları başkalarının sahip çıkması, ya da başkalarının başarısızlıklarına ortak olma durumları bile işgörenin özsaygısını kaybettiğinin bir göstergesi, öğrenilmiş çaresizliği bir unsurudur. Özsayg1 kaybının oluşması örgüt içinde işgörenin kariyer kararı ve kariyer beklentisini etkilemektedir. Böyle bir durumda işgören kariyer kararını sağlıklı bir şekilde veremeyecek ve hatta kısa vadede kariyer beklentisi içinde olmayacaktır. Zira ortada belirsiz bir durum, işgörenin iyi niyetli tutum ve davranışı ve kariyer ile ilgili bir kararsızlık söz konusudur.

Örgüt içinde işgörenlerin mevcut durumunu koruma, sahip olduğu olanak, pozisyon, gelir ve çalışma koşullarını düşünerek ortama uyum sağlama çabası içinde olması son derece doğal karşılanır. Ancak (bu araştırma bulguları da göstermekte) işgörenlerin kariyerleri ile ilgili karar verme ve kariyer beklentisinde öğrenilmiş çaresizlik olarak da değerlendirilen "ortama uyum” faktörü etkili olmamaktadır. Çünkü ortama uyum, mevcut durumu korumaya yöneliktir ve geleceğe dair plan içermez. Bu da işgörenlerin kariyer planlarını gerçekleştirmek için başka arayış içinde olduğunu, mevcut işletmeyi düşünmediğini, daha iyi koşullarda başka bir iş bulduğunda işten ayrılacağını göstermektedir.

İşgörenin örgüt içinde hissettiği değersizlik alg1sı kariyer kararını etkilemekte ve kariyer beklentisine yöneltmemektedir. Doğal olarak işgören değer bulmadığı bir örgüt içinde kariyerine yönelik beklenti içinde olmayacaktır. Buna bağlı olarak kariyer kararını vereceği için değersizlik algısının bu karar üzerinde etkisi olduğunu belirtmek mümkündür. Ancak değersizlik algısı içinde olan işgörene sunulan kariyer olanaklanını değerlendirmesi konusunda farklı tutum ve davranış sergilemesi söz konusu olabilmektedir. İşgören çeşitli nedenlerden dolayı kariyer olanaklarını değerlendirmede değersizlik algısı etkisinde kalabilmektedir. Diğer yandan örgüt içinde karşılaştığ1 sorunların yarattı̆̆ motivasyon kaybı, iş çıktıları kadar işgörenlerin gelecek planlarını da etkileyebilmektedir. Öğrenilmiş çaresizliğin bir sonucu olarak da ortaya çıkan motivasyon kaybı işgörenlerin kariyer kararları ve kariyer beklentisini etkilemektedir.

Sonuç olarak, öğrenilmiş çaresizlik işgörenlerin çalışma yaşamında hem mevcut tutum ve davranışlarını hem de geleceğe yönelik hedef ve beklentilerini doğrudan ya da dolaylı olarak etkilemektedir. Özellikle işgörenlerin kariyer planlaması içinde kararı, beklentisi ve olanakların değerlendirilmesinde etkili olan öğrenilmiş çaresizlik tüm boyutlarıyla bir örgütsel davranış sorunlarından birisi olarak değerlendirilebilir. Bu sorun hem bireysel hem de örgütsel düzeydeki belirli olumsuz sonuçları ortaya çıkarmakta ve iş yaşamında üzerinde önemle durulmasını göstermektedir. Diğer yandan bu çalışmada elde edilen sonuçları genellemek doğru olmayacaktır. Farklı boyutlarıyla daha geniş bir çalışma alanı ve evrende araştırılması önemli sonuçları ortaya çıkaracaktır.

\section{Etik Beyan}

"Otel Issletmelerinde Öğrenilmis Caresiz̧lik ve Kariyer Planlaması Arasındaki İlişkinin Analiz̨i” başlıklı çalışmanın yazım sürecinde bilimsel, etik ve alıntı kurallarına uyulmuş; toplanan veriler üzerinde herhangi bir tahrifat yapılmamış ve bu çalışma herhangi başka bir akademik yayın ortamına değerlendirme için gönderilmemiştir".

\section{Kaynakça}

Abramson, L. Y. Seligman, M. E. ve Teasdale, J. D. (1978). Learned helplessness in human: Critique and reformulation. Journal of Abnormal Psychology (87), 49-74.

Alloy, L. B., Peterson, C., Abramson, L. Y. ve Seligman, M. E. (1984). Attributional style and the generality of learned helplessness. Journal of Personality and Social Psychology, 46(3), 681-687 
Aydın, G. (1986). Çocuklarda arkadaş ilişkilerinde başarısızlık ve öğrenilmiş çaresizlik ilişkisi. Psikoloji Dergisi, 5 (20), 9-16.

Bagdadli, S. ve Gianecchini, M. (2018). Organizational career management practices and objective career success: A Systematic review and framework. Human Resource Management Review.

Ballakrishnan, L. ve Srividhya, S. (2007). Human resource development. Delhi: Himalaya Publishing House.

Baum, T. (2015). Human resources in tourism: still waiting for change?-A 2015 reprise. Tourism Management, 50, $204-$ 212.

Bayraktaroğlu, S. (2016). Insan kaynaklar yönetimi (6. b.). İstanbul: Avc1 Ofset.

Boichuk, J. P., Bolander, W., Hall, Z. R., Ahearne, M., Zahn, W. J. ve Nieves, M. (2014). Learned helplessness among newly hired salespeople and the influence of leadership. Journal of Marketing, 78(1), 95-111.

Budak, G. ve Budak, G. (2004). Issletme yönetimi. İzmir: Fakülteler Kitabevi.

Chetana, N. ve Mohapatra, A. K. (2017). Career planning and career management as antecedents of career development: A study. Asian Journal of Management, 8(3), 614-618.

Chitrakar, R. (2017). Organization Culture and Learned Helplessness. Journal of HR, Organizational Behaviour \& Entrepreneurship Development, 1(1), 17-20.

Costello, C. G. (1978). A critical review of Seligman's laboratory experiments on learned helplessness and depression in humans. Journal of Abnormal Psychology, 87(1), 21-31.

Degago, E. (2014). A study on impact of psychological empowerment on employee performance in small and medium scale enterprise sectors. European Journal of Business and Management, 6(27), 60-72.

Demir, M. (2011). İşgörenlerin çalışma yaşamı kalitesi algılamalarının işte kalma niyeti ve işe devamsızlık ile ilişkisi. Ege Akademik Bakıs Dergisi, 11(3), 453-464.

Demir, M. (2014a). Seyahat acentacllı̆g ve tur operatörlüğü. Ankara: Detay Yayıncilık.

Demir, M. (2014b). İşgörenlerin adalet algılamaları kapsamında sessizlik davranışının kariyer beklentisi ile ilişkisi. Uluslararasi Insan Bilimleri Dergisi, 11(1), 1095-1113.

Demir, M. ve Demir, Ş. Ş. (2012). Yükseköğretim kurumlarında örgütsel sessizlik: turizm lisans eğitimi kurumları örneği. Milli Ë̆̈tim Dergisi, 41(193), 184-199.

Demir, M. ve Demir, Ş. Ş. (2016). Akademik beklenti, akademik memnuniyet ve kariyer planlaması ilişkisi: Turizm lisans öğrencileri örneği. Uluslararası İnsan Bilimleri Dergisi, 13 (1), 46-59.

Di Fabio, A., ve Saklofske, D. H. (2014). Comparing ability and self-report trait emotional intelligence, fluid intelligence, and personality traits in career decision. Personality and Individual Differences, 64, 174-178.

Ersever, H. (1993). Öğrenilmiş çaresizlik. Ankara Üniversitesi Eğitim Bilimleri Fakültesi Dergisi, 26 (2), 622-632.

Gati, I. ve Levin, N. (2014). Counseling for Career decision-Making difficulties: Measures and Methods. The Career Development Quarterly, 62(2), 98-113.

Greco, L. ve Kraimer, M. (2018). Goal-setting in the career management process: An identity theory perspective. In Academy of Management Proceedings (Vol. 2018, No. 1, p. 15563). Briarcliff Manor, NY 10510: Academy of Management.

Gönül, B. K. (2018). Öğrenilmiş çaresizlik ve kariyer planlaması arasındaki ilişki (Yüksek Lisans Tezi). Süleyman Demirel Üniversitesi, Isparta.

Hernaus, T., Pavlovic, D. ve Klindzic, M. (2019). Organizational career management practices: The role of the relationship between HRM and trade unions. Employee Relations, 41(1), 84-100

Hiroto, D. S. ve Seligman M. E. P. (1975). Generality of learned helplessness in man. Journal of Personality and Social Psychology, 31(2), 311-327.

Hovardaoğlu, S. (1986). Öğrenilmiş çaresizlik modeli. Psikoloji Dergisi , 5 (20), 3-8.

Hovardaoğlu, S. (1990). Öğrenilmiş çaresizlik ve depresyon: yükleme biçimi ölçeği ve Beck depresyon ölçeğiyle yapılan bir çalışma. Ankara DTCF Dergisi, 33 (1-2), 221-230.

Huang, X. (2012). Helplessness of empowerment: The joint effect of participative leadership and controllability attributional style on empowerment and performance. Human Relations, 65(3), 313-334.

Jackson, D. ve Wilton, N. (2017). Perceived employability among undergraduates and the importance of career selfmanagement, work experience and individual characteristics. Higher Education Research \& Development, 36(4), $747-$ 762.

Karlsson, J. C. (2012). Dignity and autonomy at work. In Organizational Misbehaviour in the Workplace (pp. 3-18). Palgrave Macmillan, London.

Kim, S. O. (2016). The relationship among self-efficacy, career decision making types and career decision level of nursing students. Journal of Korean Academic Society of Nursing Education, 22(2), 210-219.

Lawrence, J. S. ve Crocker, J. (2009). Academic contingencies of self-worth impair positively-and negativelystereotyped students' performance in performance-goal settings. Journal of Research in Personality, 43(5), 868-874.

Lewis, J. A., Raque-Bogdan, T. L., Lee, S. ve Rao, M. A. (2018). Examining the role of ethnic identity and meaning in life on career decision-making self-efficacy. Journal of Career Development, 45(1), 68-82.

Maier, S. F. ve Seligman, M. E. (2016 ). Learned helplessness at fifty: insights from neuroscience. Pschological Review, 349-367.

Martincin, K. M. ve Stead, G. B. (2015). Five-factor model and difficulties in career decision making: A metaanalysis. Journal of Career Assessment, 23(1), 3-19. 
McMullen, M. B. ve Krantz, M. (1988). Burnout in day care workers: The effects of learned helplessness and selfesteem. Child and Youth Care Quarterly, 17(4), 275-280.

Milliken, F. J., Schipani, C. A., Bishara, N. D. ve Prado, A. M. (2015). Linking workplace practices to community engagement: The case for encouraging employee voice. Academy of Management Perspectives, 29(4), 405-421.

Moreland, J. J., Ewoldsen, D. R., Albert, N. M., Kosicki, G. M. ve Clayton, M. F. (2015). Predicting nurses' turnover: the aversive effects of decreased identity, poor interpersonal communication, and learned helplessness. Journal of Health Communication, 20(10), 1155-1165.

Overmier, J. B. ve Seligman, M. E. (1967). Effects of inescapable shock upon subsequent escape and avoidance responding. Journal of Comparative and Physiological Psychology, 63(1), 28-33.

Southiseng, N. ve Walsh, J. (2011). Study of tourism and labour in luang prabang province. Journal of Lao Studies, 2(1), 45-65.

Tiggemann, M. ve Winefield, A. H. (1984). The effects of unemployment on the mood, self-esteem, locus of control, and depressive affect of school-leavers. Journal of Occupational Psychology, 57(1), 33-42.

Tütüncü, Ö. ve Demir, M. (2002). Konaklama Issletmelerinde Insan Kaynaklar Yönetimi ve Isgü̈cü Hareketlerinin Analiži, Ankara: Turhan Kitabevi.

Wang, M. ve Wanberg, C. R. (2017). 100 years of applied psychology research on individual careers: From career management to retirement. Journal of Applied Psychology, 102(3), 546-563.

$\mathrm{Yu}$, C. (2017). Managers promote knowledged staff's person-career fit: career self-management and perceived organizational support. Eurasia Journal of Mathematics, Science and Technology Education, 13(8), 5173-5184.

Yüksel, F. ve Özkiraz, A. (2012, February 1). The main problem of turkish public administration: Learned helplessness. African Journal of Business Management, 6(4), 1214-1221

\section{EXTENDED ABSTRACT}

People need to work not only for meeting basic and special needs but also for socializing. Whatever a person's purpose is, satisfying his/her need to work is his/her career. "Work" would be a personal one or an organized one. Career can be described as opportunities that employees catch throughout their working life, material or spiritual gains, satifactory accomplishments or social or mental positions that makes the life easier. Organized working environment shapes the employees, their expectations, relationships and decisions. It also causes both positive and negative outcomes of the employee's actions. Development of the employee's career is an important subject for organizations because the most important aspect of an organization is human power. Career development gives the employee experience, maturity and expertise and this directly affects the quality and quantity of organizational outcomes. In an organization, this kind of a development increases the contribution of the employee to the product or service. Career Planning, which is the subject of this work, is a part of career management which includes preperation, implementation and supervision of personal or organizational career plans.

Organizational Justice and equality in career management affects not only the performance of the employees but also the intention to stay in the company and loyality to the organization. Perception of justice in company also affects personal career planning positively. In many companies carrier planning errors in organization level lead to lack of hope and loyality in employees and quiting the job. Employees would suffer helplessness because staying in the company won't develop their career plans. This leads to workers to engage in different searches, to leave their jobs, to work in an unhappy and inefficient way even if they stay in the business. Such emotions and thoughts can lead to waste of resources in organizations.

Learned helplessness is relatively a new concept. This concept was put forward by Owermier and Seligman (1967), who studied on social learning. Learned helplessness is a physical term, a mental state in which an organizm forced to be aversive stimuli, or stimuli that are painfull or otherwise unpleasent becomes unable, or unwiling to avoid subsequent counters with those stimuli, even they are "escapable", presumably because it has learnt that it can not control the situation.

It is argued that employee suffering from learned helplessness would lose his connection to the circumstance that lead to learned helplessness and generalize the feeling to all circumstances in his life but it requires some preconditions the importance of uncontrollable situation and the expectation for a solution are main factors contributing to the learned helplessness. The modal is somehow critisized for excluding personal differences and lack of determination of the individual suffering from learned helplessness.

Inclusion of personal helplessness and lack of talent to modified modal are not enough to observe learned helplessness. In addition modified modal considers the loading of generality degree as an 
important variable. In modified modal helpless individual firstly discovers that some outcomes and answers are independent and than explains why. That referance determines his future expectations for cause and effect relations and intensity of the helplessness.

In working life, learned helplessnes has some indicators. Despair due to negative experiences in working life and acception of the situations is one of them. Sense of failure, repating problems and failure in a specific task can lead to acceptance of failure. Moreover, working of the employee in the same position for a long time is also a indicator of acceptions. Another indicator of learned helplessness is lack of "self-respect".

Despite the efforts of the worker within the organization, constant obstruction that leads to intention to escape responsibility is considered as helplessness. Although the employees within the organization don't want to, they may occasionally act as "adapting to the environment" by remaining silent in order to adapt to the general situation. if a rule and practice in the workplace is incorrect, or if a business person who wants to have good relations in the workplace may be able to lose his or her current status may act in compliance by acknowledging that he does not have the power to change them. Another indicator of learned helplessness is the "perception of worthlessness" it has created in the workplace. The worker whose efforts and suggestions, which is not taken into account, to correct the wrong rules and practices in the workplace, can show helplessness by feeling worthless within the organization. Hypotheses of the study have been established within the framework of the information obtained from the literature.

This research focuses on examining the relationship between learned helplessness and career at the organizational level. The research is limited to the qualifications measured by the variables of the "Learned Helplessness Scale" and "Career Planning Scale" of tourism business-certified accommodation enterprises operating in Ankara. The research universe consists of 181 hotel businesses. 140 of these businesses responded positively to the request for interviews. However, 41 businesses responded negatively to the survey application. 1200 questionnaires were distributed and data was collected in a healthy manner. As a result of two-stage evaluation, 405 questionnaires were determined to be reliable.

SPSS22 program was used in the study when analyzing the data. Based on the information in the literature on learned helplessness, 5 dimensions were formed: "acceptance", "loss of self-esteem", "adaptation to the environment" "perception of worthlessness" and "loss of motivation". Learned helplessness in the "acceptance" dimension has been seen to emerge as unresponsiveness. By analysis and variables of "loss of self-esteem", it is understood that the behaviors of self-esteem of workers in organizations in general include and learned helplessness behavior creates a reduction in one's self-esteem. The analysis results explain that behavior of the workers in organizations generally involve adaptation behaviors in the "environment" dimension and that learned helplessness behavior requires compliance with the current conditions and acting accordingly. In the last factor "loss of motivation", it was understood that the employees in the organization in general experienced loss of motivation and learned helplessness causing loss of motivation and loss of productivity in the employees. 